\title{
TINDAK PIDANA TERORISME DARI PERSPEKTIF HUKUM PIDANA INTERNASIONAL ${ }^{1}$
}

\author{
Oleh: Rachmayanthy \\ Dosen Program Magister Hukum Universitas Pamulang \\ E-Mail: yanthyrachma@yahoo.co.id
}

\begin{abstract}
Abstrak
Tindak pidana terorisme termasuk kejahatan transnasional berdasarkan konvensikonvensi internasional. Kejahatan/ pidana transnasional dimaksud adalah untuk menunjukan adanya kejahatan-kejahatan yang pada dasarnya bersifat nasional namun mengandung aspek transnasional atau lintas batas negara. Pidana transnasional dalam konvensi, bertujuan tidak lebih dari pengaturan mengenai bentuk kerjasama dalam memberantas kejahatan nasional yang melewati lintas batas negara. Terorisme belum masuk ke dalam bentuk tindak pidana internasional disebabkan belum adanya unifikasi tentang pengertian terorisme. Kesulitan menyeragamkan pengertian terorisme disebabkan sifat sensitif pemahaman masing-masing negara berkaitan dengan aspek ras, etnis, budaya, agama, geografi masing-masing negara. Proses penegakan hukum terorisme dilakukan pada yurisdiksi hukum positif negara secara nasional bukan pada yurisdiksi mahkamah pidana internasional berdasarkan statuta roma.
\end{abstract}

Kata Kunci: Tindak Pidana, Terorisme, Hukum Pidana Internasional

\begin{abstract}
Terrorism is one of transnational crime base on international conventions. One of national crime which consists of transnational aspects. Transnational crime convention only manage about how to run cooperation to eliminate national crime which across country borders. Terrorism hasn't consider as International crime because there's no unification about its definition. Terrorism still consider as a sensitive issue in each country related with rass, etnis, culture, religion, and geographical aspects. Terrorism law enforcement proses is each country positive law jurisdiction and not as International Criminal Court jurisdiction based on Rome Statuta.
\end{abstract}

Keywords: Crime, Terrorism, International Criminal Law

\section{A. Pendahuluan}

Kejahatan terorisme merupakan salah satu bentuk kejahatan berdimensi internasional, karena segala bentuk aksi-aksi teror yang dilakukannya sangat menakutkan masyarakat dan telah banyak memakan korban yang terjadi diberbagai negara di dunia. Konvensi internasional juga memberikan penjelasan tentang tindak pidana terorisme masuk dalam salah satu jenis tindak pidana internasional yang memiliki aspek internasional dan dapat disebut sebagai kejahatan terhadap masyarakat

\footnotetext{
${ }^{1}$ Naskah diterima tanggal 4 Maret 2016, direvisi: 17 April 2016, disetujui untuk terbit 29 Juni 2016 dalam Volume 3 No. 1 Juli 2016
} 
internasional (delicia juris Gentium). Hal ini sejalan dengan ditetapkannya tindak pidana teroris dalam convention for the prevention and punishment of terrorism di Genewa, 1937, International convention for the supresión of terrorism Bombing 1998 dan Internasional covention for the supresión of the financing of terrorism, 1999 sebagai kejahatan transnasional (transnational crimes) ${ }^{2}$.

Meskipun terorisme disebutkan merupakan kejahatan yang bersifat internasional, tetapi sampai saat ini terorisme belum diakui sebagai kejahatan internasional (international crime) oleh PBB, bahkan usaha memasukan terorisme ke dalam yurisdiksi Mahkamah Pidana Internasional (International Criminal Court) dalam Konvensi Diplomatik di Roma tahun 1998 telah ditolak, terutama oleh negara-negara OKI dan juga Amerika Serikat ${ }^{3}$.

Bila aspek tindak pidana terorisme ada di dalam pidana internasional maka terorisme merupakan salah satu dari kejahatan internasional di dalam perspektif hukum pidana internasional, sehingga dapat dijelaskan bahwa hukum pidana internasional pada dasarnya mencakup aspek-aspek hukum pidana yang berdimensi internasional. Sedangkan kata internasional menunjukan hal-hal yang bersifat lintas batas negara yang melibatkan lebih dari satu negara.

Berdasarkan uraian diatas tulisan ini hendak menjelaskan tentang tindak pidana terorisme dari perspektif hukum pidana internasional.

\section{B. Pembahasan}

Hukum pidana internasional yang merupakan disiplin baru dalam ilmu hukum ditemukan beberapa terminologi yang hampir serupa, namun memiliki arti yang berbeda. Terminologi-terminologi tersebut antara lain; hukum pidana internasional, pidana internasional dan pidana trasnasional.

Sedangkan yang dimaksud Hukum pidana internasional, menunjukan adanya sekumpulan kaída-kaidah dan asas-asas hukum pidana yang mengatur tentang tindak pidana internasional. Sedangkan pidana internasional (tindak pidana internasional) menunjukan adanya suatu peristiwa kejahatan yang bersifat internasional, yaitu

\footnotetext{
2 Abdussalam, Andri Desasfuryanto, Hukum Pidana Internasional, Penerbit PTIK, Jakarta, Cetakan ke-3,2012, hlm.22

${ }^{3}$ Romi Atmasasmita, Pengantar Hukum Pidana Internasional, Bagian II, Penerbit PT. Hecca Mitra Utama, Jakarta, 2004, hlm.83.
} 
kejahatan-kejahatan yang diatur dalam konvensi-konvensi internasional sebagai tindak pidana internasional, sedangkan istilah pidana trasnasional (tindak pidana trasnasional) dimaksudkan untuk menunjukan adanya tindak pidana yang pada dasarnya bersifat nasional namun mengandung aspek transnasional atau lintas batas negara ${ }^{4}$

Berdasarkan ditetapkannya tindak pidana teroris oleh beberapa konvensi internasional pada tahun 1937, 1998 dan 1999 sebagai kejahatan transnasional (transnational crimes). Dimana pidana transnasional adalah kejahatan domestik atau kejahatan yang bersifat nasional namun melewati batas wilayah negara. Hal ini diperjelas dalam pasal 2 Konvensi Palermo 2000, konvensi menentang kejahatan transnacional terorganisasi yang menyatakan, bahwa kejahatan bersifat transnasional jika:

1. dilakukan di lebih dari satu negara;

2. dilakukan di satu negara tetapi bagian substantif dari persiapan, perencanaan, pengarahan dan pengawasannya dilakukan di negara lain;

3. dilakukan di satu negara tetapi melibatkan suatu kelompok kejahatan terorganisasi yang ikut serta dalam kegiatan kejahatan di lebih dari satu negara

4. dilakukan disuatu negara tetapi telah memberikan dampak yang cukup besar di negara lain.

Sejauh ini masih terdapat perdebatan mengenai keberadaan pidana trasnasional sebagai objek kajian Hukum Pidana Internasional mengingat kejahatan yang dikategorikan sebagai pidana trasnasional benar-benar hanyalah berupa kejahatan domestik atau kejahatan nasional biasa namun memiliki kriteria-kriteria khusus ${ }^{5}$.

Lebih jauh terorisme, dari beberapa literatur dalam konvensi-konvensi internasional memberikan penjelasan tentang tindak pidana terorisme masuk dalam salah satu jenis tindak pidana internasional yang memiliki aspek internasional dan dapat disebut sebagai kejahatan terhadap masyarakat internasional (delicia juris Gentium).

Sehingga jika dilihat tindak pidana terorisme seperti memiliki 2 (dua) sisi pemahaman, satu sisi terorisme bersifat kejahatan internasional yang merupakan kejahatan lintas batas (transnational) yang penegakan hukumnya melalui proses

${ }^{4}$ I Wayan Parthiana, Hukum Pidana Internasional, Penerbit Irama Widya, Bandung 2006, hlm.31-32

${ }^{5}$ Tolib Effendi, Hukum Pidana Internasional, Penerbit Pustaka Yustisia, 2014, hlm.35. 
peradilan nasional, di lain sisi belum ada pengakuan oleh PBB sebagai kejahatan internasional.

Lebih lanjut perbedaan tersebut disebabkan adanya pengertian dari terorisme itu sendiri, pengertian terorisme sangat majemuk dan multi interpretatif, sehingga akibatnya belum ada kesepakatan atau keseragaman yang dapat diterima secara universal tentang pengertian terorisme.

Di dalam konvensi tentang pencegahan dan penghukuman terhadap terorisme pada tanggal 16 November 1937 dimuat ketentuan mengenai kewajiban-kewajiban negara peserta untuk menetapkan tindakan terorisme sebagai suatu tindakan yang memiliki karakter internasional, dengan demikian tindakan terorisme yang dilakukan di negara lain dapat dihukum berdasarkan hukum pidana negara yang berkepentingan. Selain hal tersebut, di dalam konvensi ini tindakan ekstradisi diperluas meliputi kejahatan politik dan menegaskan kerjasama kepolisian antara negara-negara penandatanganan konvensi ini. Suplemen atas isi konvensi mengenai pembentukan pengadilan (pidana) internasional tidak pernah dilaksanakan sampai saat ini. ${ }^{6}$

Terorisme masuk dalam lingkup tindak pidana internasional dinyatakan oleh Dautricourt didalam karya tulisnya, "The Concept of International Criminal Jurisdiction-Definition and Limitation of the Subject" (1973) menyebutkan beberapa international crimes sebagai berikut: terrorism (terrorisme); slavery (perbudakan); the slave trade (perdagangan budak); traffic in women and children (perdagangan wanita dan anak-anak); traffic in narcotic drugs (perdagangan illegal narkotika); traffic in pornographic publication (peredaran publikasi pornografi); piracy (pembajakan dilaut); aerial highjacking (pembajakan udara); counterfeiting (pemalsuan mata uang); the destruction of submarine cables (perusakan kabel-kabel dibawah laut) ${ }^{7}$. Namun Daurtricourt masih meragukan apakah terorisme dan pembajakan diudara dapat disebut sebagai delicia juris Gentium.

Kesulitan mendapatkan kesepakatan atau keseragaman yang dapat diterima secara universal yaitu tentang pengertian terorisme, maka dapat dimengerti jika kemudian beberapa pakar atau negara memberikan pengertian terorisme sesuai sudut pandangnya.

\footnotetext{
${ }^{6}$ Romli Atasasmita, Pengantar Hukum Pidana Internasional,, Penerbit PT Refika Aditama, Cetakan ke-1, September 2000, hlm. 11.

${ }^{7}$ Ibid , hlm 44-45.
} 
Pengertian terorisme menurut Brian Jenkin, ${ }^{8}$ terorisme adalah: A strategy of violence designed to promote desired outcomes by instilling fear in the public at large (sesuatu strategi kekerasan yang dirancang untuk meningkatkan hasil-hasil yang diinginkan, dengan cara menanamkan ketakutan dikalangan masyarakat umum). Terorisme adalah...the use or threaten use of force designed to bring about political change,...(penggunaan atau encaman penggunaan kekerasan yang bertujuan untuk mencapai terjadinya perubahan politik).

Sedangkan Hoffman ${ }^{9}$ memberikan arti teroris adalah: Terrorism is a purposeful human political activity which is directed toward the creation of general climete of fear, and is designed to influence, in ways desired by the protagonist, other human beings and, through them, some corpuse of events (Hoffman,1999). (Terorisme adalah suatu aktivitas politis manusia yang dilakukan dengan sengaja dan diarahkan pada penciptaan iklim ketakutan pada umumnya, dan dirancang untuk mempengaruhi, dalam berbagai cara yang diinginkan oleh pelaku, manusia lain dan melalui mereka, beberapa rangkaian peristiwa).

James Adams ${ }^{10}$ di dalam bukunya Financing of Teror, How The Groups That Are Terrorizing The Word Get The Money to Do it, memberikan pengertian bahwa terorisme adalah penggunaan atau ancaman kekerasan fisik oleh individu-individu atau kelompokkelompok untuk tujuan-tujuan politik, baik untuk kepentingan atau untuk melawan kekuasaan yang ada, apabila tindakan-tindakan terorisme itu dimaksudkan untuk mengejutkan, melumpuhkan atau mengintimidasi suatu kelompok sasaran yang lebih besar dari pada korban-korban langsungnya.

Meskipun belum ada kesepakatan atau keseragaman yang dapat diterima secara universal tentang pengertian terorisme, tetapi menurut James Adams terdapat beberapa kesamaan pendapat mengenai ciri-ciri dasar dari terorisme, yaitu pengeksplotasian kelemahan-kelemahan manusia secara sistematik (kengerian atau ketakutan yang melumpuhkan terhadap kekerasan/ kekejaman/ penganiayaan fisik); penggunaan atau ancaman penggunaan kekerasan fisik; adanya unsur pendadakan/ kejutan; mempunyai

\footnotetext{
${ }^{8}$ A.M.Hendropriyono, Terorisme, Penerbit Buku Kompas, Jakarta, Cetakan ke-1, Oktober 2009, hlm.26.

${ }^{9}$ Petrus Reinhard Golose, Deradikalisasi Terorisme, Penerbit Yayasan Pengembangan Kajian Ilmu Kepolisian, Jakarta, Cetakan ke-1, Agustus 2009, hlm.3.

${ }^{10}$ Poltak Pantogi Nainggolan, Terorisme dan Tata Dunia Baru, Penerbit Pusat Pengkajian dan Pelayanan Informasi Sekretaris Jenderal Dewan Perwakilan Rakyat, Yakarta, 2002.hlm.106.
} 
tujuan politik yang jauh lebih lama dari sasaran atau korban langsungnya; sasaran pada umumnya non kombatan direncanakan atau dipersiapkan secara rasional.

Kesulitan menyeragamkan pengertian terorisme dari sudut pandang disiplin hukum pidana internasional disebabkan beberapa aspek antara lain, ras, budaya, etnis, agama dan geografis yang berbeda di masing-masing negara. Sehingga diperlukan sifat kehati-hatian negara-negara dalam menentukan pengertian kejahatan teroris secara universal sebagai tindak pidana internasional.

\section{Penutup}

Tindak pidana terorisme merupakan tindak pidana yang bersifat internasional. Lebih lanjut dari perspektif hukum pidana internasional tindak pidana terorisme termasuk dalam lingkup pidana transnasional sebagai objek kajian hukum pidana internasional.

Sejauh ini masih terdapat perdebatan mengenai keberadaan pidana trasnasional sebagai objek kajian Hukum Pidana Internasional mengingat kejahatan yang dikategorikan sebagai pidana trasnasional benar-benar hanyalah berupa kejahatan domestik atau kejahatan nasional biasa namun memiliki kriteria-kriteria khusus.

Kreteria khusus dari tindak kejahatan terorisme antara lain; adanya penggunaan atau ancaman kekerasan fisik untuk tujuan-tujuan politik, baik untuk kepentingan atau untuk melawan kekuasaan yang ada, adanya tindakan-tindakan meneror dengan maksud untuk mengejutkan, melumpuhkan atau mengintimidasi suatu kelompok sasaran sehingga mengakibatkan adanya korban secara langsung maupun korban lebih besar, adanya kesengajaan yang diarahkan pada penciptaan iklim ketakutan pada umumnya, dan adanya irancangan untuk mempengaruhi, dalam berbagai cara yang diinginkan oleh pelaku.

Pidana transnasional dalam konvensi, bertujuan tidak lebih dari pengaturan mengenai bentuk kerjasama dalam memberantas kejahatan nasional yang melewati lintas batas negara. Kerja sama ditujukan agar pelaku kejahatan yang melewati lintas batas negara tersebut dapat dijerat oleh hukum, melalui perjanjian ekstradisi antar negara-negara di dunia terkait tindak pidana terorisme. 


\section{Daftar Pustaka}

A.M.Hendropriyono, Terorisme, Penerbit Buku Kompas, Jakarta, Cetakan ke-1, Oktober 2009

Abdussalam, Andri Desasfuryanto, Hukum Pidana Internasional, Penerbit PTIK, Jakarta, Cetakan ke-3,2012

I Wayan Parthiana, Hukum Pidana Internasional, Penerbit Irama Widya, Bandung 2006

Petrus Reinhard Golose, Deradikalisasi Terorisme, Penerbit Yayasan Pengembangan Kajian Ilmu Kepolisian, Jakarta, Cetakan ke-1, Agustus 2009

Poltak Pantogi Nainggolan, Terorisme dan Tata Dunia Baru, Penerbit Pusat Pengkajian dan Pelayanan Informasi Sekretaris Jenderal Dewan Perwakilan Rakyat, Yakarta, 2002

Romi Atmasasmita, Pengantar Hukum Pidana Internasional, Bagian II, Penerbit PT. Hecca Mitra Utama, Jakarta, 2004

Tolib Effendi, Hukum Pidana Internasional, Penerbit Pustaka Yustisia, 2014

Romli Atasasmita, Pengantar Hukum Pidana Internasional,, Penerbit PT Refika Aditama, Cetakan ke-1, September 2000 